\title{
Eestlaste arvamus eurooplastest I. Etnilistest stereotüüpidest ${ }^{1}$
}

\author{
Mare Kõiva \\ Liisa Vesik
}

Teesid: Sotsiaalteadustes ulatuslikult teoreetilistes ja rakendusuuringutes käsitletud stereotüüpide ja eelarvamuste teema on seni humanitaarias vähe tähelepanu pälvinud, kasutatud eeskätt huumori ja kujundkõne, ka diasporaa-uuringutes. Samas stereotüübid (folkloristiklik termin käibetõde) kajastuvad folkloori erinevates liikides ja mitmed liigid põhinevad otseselt stereotüüpidel. Artikkel käsitleb etnilisi stereotüüpe 2009. aastal YouTube'i postitatud animatsiooni “"Yurop” According to Estonians" ning 2000. aastal kuue etnilise rühma/rahva kohta läbiviidud küsitluse põhjal, mida võrreldakse varasemate uurimistulemustega. "Yuropi" stereotüübid korreleeruvad küsitlustulemustega, kuid animatsioonis on konkreetse maa ja rahva kohta lausutul meedia mõju ja ajastu pitser. Küsitlustulemused eksponeerivad rootslasi, lätlasi, sakslasi positiivsete stereotüüpide kaudu, negatiivseid stereotüüpe kutsuvad esile Soome ja Venemaa (võimalik, et frustratsiooni ja võistlusmomendi põhjustatud) ja USA (võimalik põhjustaja meediasurve igapäevakultuurile, globaliseerumisprotsessi negatiivsete külgede neile omistamine). Küsitlustulemused osutavad, et stereotüübid kohandatakse uute sotsiaalkultuuriliste jm oludega, kuid etnilise rühma erinevad segmendid ja isiksused võtavad need erineva kiirusega omaks; teatav osa stereotüüpe püsib pikka aega. Eestlaste enesehinnang ja autostereotüüpide koosseis on muutunud: endine üheksa positiivset kümnest on asendunud kuue (vahel enama) positiivse stereotüübiga.

${ }^{1}$ Artikkel on valminud ETF grandi 8137 "Kultuuriprotsessid Interneti kogukondades. Narratiivid, väärtushinnangud ja kohaloome” raames. 
Märksõnad: autostereotüüp, eelarvamus, etnilised stereotüübid, käibetõde, stereotüüp, YouTube

YouTube on üks tuntuimaid osalusmeedia keskkondi. Kasutajate loodud videote esitlemisplatvorm koos kommentaaridega esindab spontaanset loomulikku arhiivi. Seda igas mõttes, kõige laiemast kitsamani, koos sinna juurde kuuluvate muutustega. Vaatleme animatsiooni, graafilist ja verbaalset klippi “"Yurop" According to Estonians" $(2009)^{2}$ (http://www.youtube.com/watch?v=NHW7DCP8_ GE ). ${ }^{3}$ See transmediaalne narratiiv kujutab endast otsekui jutustust eestlaste stereotüüpidest, eelarvamustest ja tavafilosoofiast Euroopa rahvaste kohta aastal 2009. Narratiivina sisaldab "Yurop" intertekstuaalseid viiteid ja siduselemente erinevate meedialugude ja -uudistega, osutab meedia mõjutustele arvamuste kujundamisel, ent seekordses käsitluses keskendume ennekõike klipis avalduvatele stereotüüpidele.

Avalik arutelu lehekülje ümber osutab stereotüüpide universaalsusele, kuid isegi osa väga spetsiifilistest stereotüüpidest ületab etnilise rühma ja lokaalsuse piirid ning suudab naerutada erinevaid rahvaid. "Yurop" on visuaalse huumori näide, mis sisaldab sarnaselt igasugusele satiirile tõetera.

Stereotüüpe käsitletakse rühma kohta levivate liialdatud või ekslike üldistustena, mis ei laiene ega kehti konkreetse rühma üksikliikmete kohta. Enamasti käsitletakse stereotüüpe negatiivses võtmes, samas unustatakse need üldistused, mis näitavad rühma (või üksikisikuid) heas või paremas valguses. Kuna positiivseid stereotüüpe ei osata mõistega ühendada, on nende roll isiksuse või rühma representatsioonis jäänud teenimatult kõrvale. Isiklikest kogemustest lähtudes näib, et positiivseid stereotüüpe kasutatakse

${ }^{2}$ Artikkel põhineb 11. septembril 2009 konverentsil "From Language to Mind 3: On the Occasion of the 70th Birthday of Academician Arvo Krikmann" peetud ettekandel ja 20. veebruaril 2008 konverentsil "Keelest meeleni 2: pühendatud Ülo Tedre 80. sünnipäevale" peetud Mare Kõiva ettekandel "Kuue rahva stereotüübid". Artikkel on varem avaldatud ingliskeelsena: Kõiva, Mare; Vesik, Liisa 2011. "Yurop" According to Estonians: Some Ethnic Stereotypes. Witalisz, Alicja (toim). Prace naukowo-dydaktyczne Panstwowej Wyzszej Szkoly Zawodowej w Krosnie. Papers on Language, Culture and Literature. Zeszyt 55 (3). Krosno, 147-158.

${ }^{3}$ Klipi pealkiri "Yurop According to Estonians" tsenseeriti hiljem YouTube keskkonnas korrektses vormis Europe'ks, mis esindab sisust erinevat stiilikategooriat. Kasutame artiklis algset pealkirja. 


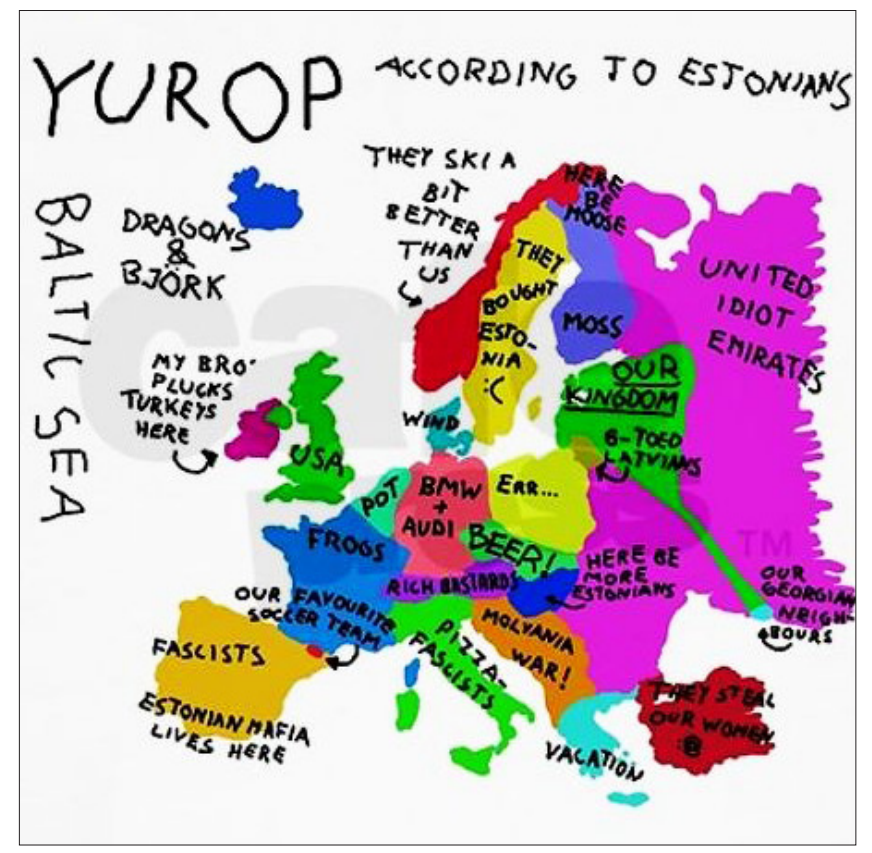

igapäevases suhtlemises või otsuste langetamisel, nad abistavad infolainetes navigeerimisel. Leviv poliitilise korrektsuse nõue on muutnud stereotüüpide uurimise keeruliseks ja kahepalgeliseks, loonud mimikrikäitumise. Isegi kui inimese tegelik hinnang teatud etniliste rühmade kohta on väga madal, ei taheta avalikult paista silma (negatiivsete) stereotüüpide kandjana.

Kõigele vaatamata on inimestel eelarvamuslikud stereotüübid. Vormiliselt käibetõdede, uskumuste ja fraseoloogiana esinevaid stereotüüpe leidub kõigis folklooriliikides, kuid nad on, nagu sotsiaalsetele silmast silma suhtlemise olukordadele iseloomulik, peidetud huumori, eneseiroonia, satiiri või üleloomulikkusega seotud emotsionaalsete väljenduste taha; tervikuna on teemat Eesti folkloristikas vähe uuritud.

Teoreetilise tausta loomise järel vaatleme lähemalt, kuidas ja missuguseid üldtuntud eelarvamusi "Yurop" esindab. Laiema diskursuse loomiseks esitame M. Kõiva 2001. ja 2005. aasta küsitluse ja muude temaatiliste uurimuste taustal ülevaate etniliste stereotüüpide dünaamikast. 


\section{Stereotüüpidest sotsiaalteadustes}

Alates Walter Lipmanni 1922. aastal avaldatud käsitlusest "Public Opinion", kus ta määratleb stereotüübid kui "meie meelte pildid inimestest ja maailma sündmustest" (Lipmann, 2003 [1922], 7), on need olnud teoreetiliste ja rakendusuuringute keskmes. Walter Lipmanni arvates ei lähtu enamik meie tegevustest mitte otsestest teadmistest konkreetsete inimeste ja sündmuste kohta, vaid põhineb lihtsustatud piltidel. Stereotüübid on meile kultuuri poolt juba defineeritud elemendid, mille me n-ö korjame üles.

Kuna stereotüüpe on peetud ühiskonda mõjutavaks sotsiaalseks faktoriks, siis on nende uurimiseks ette võetud suuremaid küsitlusaktsioone. Saadud tulemustest lähtudes on püütud stereotüüpsust nõrgendada, teadustulemusi praktikasse rakendades tõkestada ja muuta teatud suhtumiste levikut. 1932. aastal Daniel Katzi ja Kenneth Braly tehtud katsetel 100 Princetoni Ülikooli üliõpilasega (Katz, Braly 1933) ning küsitluse kordamistel 1950. ja 1967. aastal (Gilbert 1951; Karlins, Coffman, Walters 1969) paluti üliópilastel 84 omadussõna abil määratleda, mis iseloomustab kõige täpsemalt kümmet etnilist rühma. Valikusse kuulusid näiteks itaallased, inglased, sakslased, juudid, neegrid. Kõigi küsitletute vastused olid üllatavalt sarnased. Näiteks peeti inglasi sportlikeks, intelligentseteks, konventsionaalseteks, traditsioone armastavateks, konservatiivseteks; ameeriklasi industriaalseteks, intelligentseteks, materialistlikeks, edasipüüdlikeks, progressiivseteks, sakslasi konservatiivseteks, materialistlikeks, konventsionaalseteks. 1967. aasta kordusküsitlus osutas, et kuigi meediaväljaannetest olid poliitilistel kaalutlustel ja stereotüüpide tõkestamiseks need iseloomustused kõrvale tõrjutud, neid suruti alla koolihariduses ja mujal avalikes sfäärides, lootes saada etnilised stereotüübid kontrolli alla, oli märgata muutusi, kuid põhiosa neist oli säilinud muutumatuna. Peamiselt vahetusid väärtuse kategooriad, mis erinevatel kümnenditel stereotüüpides esile tõusid (nt sensitiivsust määratleti 1932. aastal harva, 1967. aastal oli see juba oluline kategooria), mis osutab eeskätt kultuurilistele trendidele.

Stephanie Madon ja tema kaasautorid üldistasid 2001. aastal korratud küsitluste ja varasemate tulemuste kõrvutamise põhjal, et stereotüübid on muutunud märkimisväärselt nii sisu kui ka konsensuse poolest, lisandunud on uusi ja nüüdisühiskonnas populaarseid arvamusi, kuid konsensuses esilekerkinud muutused 
peegeldavad pigem stereotüüpsuse kasvu kui kahanemist (Madon et al. 2001, 1005).

Stereotüüpide muutumisvõime on olnud pikemalt vaidlus- ja vaatlusfaktor. Daniel Katz ja Kenneth Braly (1933) üldistasid oma uurimuses, et stereotüübid on jäigad vaated, millel on tegelike faktidega vähe seoseid. Psühholoog Gustav Gilbert (1951) pidas stereotüüpe pigem protsessuaalseks nähtuseks, mida saab muuta ja mis võivad hääbuda, kuna poliitilised, majandus- jm tegurid tingivad paratamatult ka stereotüüpide kohanemise uute oludega. Ta esitas selle valdkonna klassikaks kujunenud näite jaapanlaste kohta, keda puudutavad stereotüübid muutusid Teise maailmasõja järel negatiivsemaks.

1990. aastate ja hilisemad uurimused keskendusid rohkem teatud rühmi, nt naisi ja mustanahalisi puudutavatele stereotüüpidele, kuid tõid esile ka rea uusi ja folkloristidele huvitavaid nähtuse funktsionaalsust jälgivaid suundi, nagu stereotüpiseerimise seosed ennustamisega, autostereotüüpide dünaamika ja nt David J. Schneideri väljendatud seisukoha, et enamik stereotüüpe sisaldab nii positiivseid kui ka negatiivseid jooni (Schneider 2004, 566). Psühholoogiaalased uurimused osutasid ka stereotüüpide olulisele kognitiivsele funktsioonile abistada meid kiire andmete sõelumise juures: informatsioonitulvas aktiveeruvad stereotüübid automaatselt. See kiirendab otsuste langetamist, kuivõrd otsustamine põhineb mh stereotüüpidel ja mitte kogu võimaliku informatsiooni detailsel analüüsimisel. Narratiivide ja eriti usundiliste juttude käsitlemisel on see üks võimalikke ja arvestatavaid analüüsisuundi.

\section{Stereotüübid eesti folkloristikas}

Eesti folkloristikas on kasutatud eelarvamuste ja stereotüüpide märkimiseks terminit käibetõde, kusjuures kategooria pole suhestatud tõesusega, kuid ka ei välista seda aspekti. Käibetõdede kategooria sisaldab uskumusi ja kujundkõne erinevaid liike. Suhteliselt lähedase sisulise mahuga terminid eelarvamus ja stereotüü $p^{4}$ on tulnud kasutusse psühholoogia ja sotsiaalteaduste mõjul.

\footnotetext{
${ }^{4}$ Kasutatud mõistete maht: stereotüüp - atribuudid, mis inimeste meelest iseloomustavad teatud rühma; autostereotüüp - enesestereotüüp ehk oma rühma iseloomustavad atribuudid (Psychology Dictionary 2012).
} 
1990. aastal tuli soome keelest adapteerituna käibele termin argiuskumus, mis enamasti piirdub formaalsete väidetega, mida ei peeta tõesteks ega usuta, kuid millel on kõnekaunistuslik või hinnanguline ülesanne. Uuemaid käibetõdesid-argiuskumusi on käsitlenud nt Risto Järv (1996), kelle käsitluses see markeerib nii eelarvamusi kui stereotüüpe.

Mõiste käibetõde on siiski laiema filosoofilise taustaga - ta on lähemas seoses tavamõistuse ja tõe filosoofiaga (nt Uus 2000) ning võimaldab argikultuuri mõtestada ja väärtustada laiemas diskursuses. Kahtlemata on oluline ka stereotüüpide motivatsiooniline taust. Undo Uus väidab:

Tavamõistus ei pü̈̈lle otsustuste absoluutselt selge ja kindla aluse poole ega rakenda rangeid - ja seega potentsiaalselt ebamõistlikke - kriteeriume faktide teadmiseks võtmisel. Ta tunnistab näiteks vabaduse tunde, mis saadab meie tahtelist aktiivsust, vaieldamatuks ja väga oluliseks faktiks meie käitumise põhiiseloomu kohta. Argimõistuse eelis nü̈̈disteaduse ees seisneb tema suuremas tolerantsuses mitmekesisuse vastu: ta ei piira ennast tähelepanu pööramisega ainult “parimat" laadi andmetele. (Uus 2001, 10.)

Eelarvamustel põhinevaid uskumusi ja kujundkõne alaliike, käibetõdesid on kogutud alates 19. sajandi teisest poolest, kuid ainestik on käsitlemist leidnud suhteliselt vähe. Ükski järgnevalt loetletud kirjutistest ei analüüsi otseselt stereotüüpe, kuid toob neid esile. Käibetõdede avaldumist on seni vaadeldud peamiselt huumori, eriti klassikaliste naljandite võtmes (Põldmäe 1941; Krikmann 2008), viimasel kümnendil etniliste anekdootide diskursuses (Laineste 2004, 2009; Krikmann 2009), vähem kujundkõne kaudu (Krikmann 2009), osalt seoses diasporaa-uuringutega (Korb 2011, 2012; Kõiva 2012). Viimase suuna muutis aktuaalseks kultuuriliste erinevuste aktsepteerimine ja vajadus kultuuride kokkupuutealal vastastikku käitumist selgitada või kultuurispetsiifikat tundma õppida. Kindlasti väljendatakse stereotüüpide kaudu erinevates folklooriliikides sotsiaalse positsiooni ja võimusuhteid. Samuti on teise (rahvus) rühma suhtes rakendatud sõnakunsti liigid seni uurimisest kõrvale jäänud, olgu põhjuseks poliitkorrektsus ja konventsioonid või temaatika kaheldamatu dünaamika ja hajusus. 


\section{Ülevaade: eestlaste auto- ja heterostereotüübid 2001. ja 2005. aastal}

Mare Kõiva 2001. ja 2005. aasta küsitlustes eestlaste stereotüüpide kohta kasutati avatud vastustega küsitluskava. Vastas kokku 207 mõlemast soost üliõpilast vanuses $20-23$ aastat. Esmalt paluti neil loetleda stereotüüpe ja kirjeldada oma arvamust kuue etnilise rühma või rahvuse kohta, samuti esitada eestlasi kui rühma iseloomustavad autostereotüübid. Teiseks paluti kirjutada, mida vastaja meelest arvavad eestlaste kohta nimekirjas loetletud rahvaste esindajad. Soovi korral võis lisada näitelugusid. Vastamine toimus auditooriumis umbkaudu tunni aja jooksul. Oma teadmised paluti kirja panna isegi sel juhul, kui teadaolevaid eelarvamusi ja stereotüüpe ei jagata või neid peetakse vääraks.

Vastusevariante polnud ette antud, loetelu tuli ise vabalt koostada, mis tähendas, et ühesõnaliste vastuste kõrval esitati ka lausevormingus ja pikemaid vastuseid. Vastajatel paluti märkida oma nimi, sugu ja vanus, soovi korral võidi jääda ka anonüümseks. Küsitluse eeskujuks oli sotsiolingvist Hille Pajupuu analoogiline varasem küsitlus, mis puudutas stereotüüpe lähi- ja keelesugulaste soomlaste ja teiste naaberrahvaste kohta, ning eestlaste autostereotüüpe (tulemused vt Pajupuu 2005).

Osa vastajatest märkis, et kahtlemata on stereotüübid ekslikud või koguni vastikud üldistused, mida nad teavad, kuid mille sõnumiga nad ei nõustu. Mitmed vastajad esitasid sel juhul ka oma isiklikke vastupidiseid kogemusi. Paar vastajat väidetavalt teadsid, kuid ei kasutanud stereotüüpe, kuid nad pidasid neid naljakateks ja kergesti meeldejäävateks.

Vaadelgem esmalt vastajate stereotüüpe teiste rahvaste kohta, esitades kõige sagedasemad ja mõned esileküündiva sõnastusega vastused:

- Lätlased: peaaegu nagu eestlased, midagi eestlaste ja slaavlaste vahepealset; slaavipärased (slaavipärasemad kui meie); külalislahked; heatahtlikud. Naljatlevatest vastustest olid sagedasemad: lätlastel on kuus sõrme või kuus varvast; räimevargad; lätlaste lemmikväljend on GEP - gorjatšije estonskije parni 'kuumad eesti poisid'.

- Sakslased: korrektsed, viisakad, tugevasti reeglites kinni; seaduskuulekad, õllesõbrad (variandina: armastavad punast 
veini (intelligents) ja õlut (plebeid)); lauljad ja tantsijad; rikkad.

- Soomlased: joodikud (joovad kõvasti / joovad liiga palju), alkohoolikud (varianditi: alati valmis pidutsema, kui kodust välja saavad); reserveeritud; hoiavad eraldi; arvavad endast hästi; (välismaal) valjuhäälsed; aeglased; naised on paksud, meestel aga õllekõhud; saun; maitsetult riietujad; rändavad palju.

- Ameeriklased: paksud, valjuhäälsed; riietuvad inetult; naiivsed; patriootlikud; keepsmailijad (naeratavad kogu aeg); small talk; Ameerika unistus; kiirtoitujad; priiskavad ülekulutajad (varianditi: poodlemissõltlased); veedavad kogu elu töötades; ei suuda iseseisvalt mõtelda; õnnega koos, kui oskavad lugeda, tõenäoliselt aga ei oska nad kirjutada.

- Rootslased: reserveeritud, raskesti ligipääsetavad; sõbralikud; haritud; tolerantsed; praktilised; lõbusad; viikingid; ilusad inimesed (variante: kaunid blondid naised ja pikakasvulised tugevad mehed); svenssonid; neil on kuningas (kuningriiklased); eestlased ei suuda neid teadmistega lüüa ledestada.

- Venelased: temperamentsed; ülevoolavalt sõbralikud; hoolitsevad, avatud; kasutavad eredaid värve ja liiga palju kosmeetikat; joodikud; sentimentaalsed; kollektiivsed inimesed.

- Eestlaste autostereotüübid: tuimad; aeglased; alluvad; vimmavedajad; arrogantsed; kõvad töötegijad; haritud; suure keeleoskusega; ei näita tundeid välja; individualistid; ilusad (varianditi: ilusad naised, ja ausalt üteldes ka hea väljanägemisega mehed); külmad, raske mõista, aga kui saad eestlasega sõbraks, siis nad jäävad sõpradeks (variante: paljud elavad metsas ega soovi naabritega rääkida); söövad sülti ja tantsivad rahvatantse.

\section{Animatsioon YouTube'is}

Animatsioon "Yurop According to Estonians" postitati YouTube keskkonda 29. aprillil 2009 ja see muutus kiiresti väga populaarseks: sellele viidati Facebookis, ta levis sotsiaalsete võrgustike kaudu ja 
selle kohta kirjutati rohkesti ingliskeelseid kommentaare. ${ }^{5}$ Kommentaaridest ilmneb ühtlasi, et animatsiooni autorid on usutavasti 20. aastates eestlastest meestudengid, kelle eesmärk oli nalja visata. Ingliskeelne heli on sisse loetud ühe autori poolt ja imiteerib kergelt multikaid (vrd Bavies ja Butthead). Animatsiooni juurde kuuluva informatsiooni hulka kuulub vastustusest lahti ülemine, mis hoiatab, et asja ei tasu võtta surmtõsiselt ning kinnitab: "See on ainult nali." Selline tähelepanu juhtimine huumorile ja mittetõesusele on silmanähtavalt mõjutatud praegustest poliitkorrektsuse strateegiatest ja kartusest, et kaebuse korral animatsioon kõrvaldatakse. Muidugi võivad seesugused teated olla mõeldud vaigistama ka etnilise vihavaenu purskeid.

Diskussiooni huvides ja arvestades internetimaterjali loomuomase ajutisusega on allpool esitatud animatsiooni nn jutustajateksti tõlge koos Euroopa stiliseeritud kaardiga. Nurksulgudes on tekstis osutatud maale, mis animatsioonis kaardil välja suurendatakse ja esiplaanile tuuakse, samas riiginime otseselt suulises tekstis ei mainita. Kaardile kirjutatud märksõnu siin ei esitata.

Nii, see on Euroopa meie, eestlaste, arvates.

Meie kuningriik [Eesti] on täpselt siin Balti mere kaldal ja meie naabrid on kuuevarbalised lätlased, siin. Neil pole üldse merekallast, neil pole saari, pole merd - mitte midagi pole. Siis on meil siin üleval Soome, mis on tuntud eeskätt oma sambla poolest. Ja üleval põhjas, seal on põdrad. Siis neist järgmine on see dildo-maa, mis ostis Eesti ära [Rootsi]. Neil on olemas kõik, mis on olemas meie kuningriigis, aga jälle - nad pole kuningriik, aga meie oleme. Ja siis on nende kõrval maa, kus suusatatakse päris hästi, peaaegu, peaaegu paremini kui meie, ma arvan [Norra]. Ja siis Põhjameres on meil riik, kus meie teada elavad harmooniliselt koos lohed ja Björk [Island].

Siis me näeme seda purpurset saart seal, see on Iirimaa, mu vend kitkub seal kalkuneid, ja mu õde samuti. Nende naaber on Ameerika Ühendriigid [Suurbritannia Ühendkuningriik].

5 "Yurop" tekitas massilise samateemaliste liikumatute piltide ja animatsioonide plahvatuse, mille teostus ulatub stereotüüpide lihtsameelsest esitusviisist arenenuma narratiivini. Seoses sellega kerkib rida huvitavaid probleeme, nagu koopia ja originaali vahekord ja kuidas seda meedialoome puhul määratleda. Üldiselt kuuluvad seesugused narratiivid, animatsioonid, staatilised pildid haara pidi kokku humoristlike ja muus võtmes teostatud düstoopiate ja utoopiatega ja on omaette huvitav teema. Lähemalt käsitletakse neid teemasid artiklis "Yurop According to Estonians 2: transmediaalne narratiiv", mis ilmub 2014. 
Siis me läheme alla lõunasse ja näeme konni. See on konnaimpeerium. Seal fašistide [Hispaania] ja konnade [Prantsusmaa] vahel on meie lemmikjalkameeskond, see on Andorra, meile meeldivad nad väga, sest me andsime neile kere peale (võitsime neid). Neil on maailma ainuke meeskond, kellele me iial oleme ära teinud. Ja siis veel koos fašistidega [Hispaania] elab Eesti maffia. Neile kuulub rannik.

Siis seal saapakujulisel maal, seal elavad pitsa-fašistid [Itaalia]. Neist järgmine on Molvaania [endine Jugoslaavia], seal käib kogu aeg sõda. Siis on meil seal Kreeka, see on koht puhkamiseks. Seal on päikesepaiste ja kogu aeg suvi. Sealt järgmine maa on suur punane riik [Türgi], nad varastavad kogu aeg meie naisi, me ei salli neid üldse, väga halvad.

Siis, tulles tagasi Lääne-Euroopasse, siis on meil seal pott [Holland]. Seal me käime potte ostmas. Te võite ka osta tuult Taanist, sest seal pole mitte midagi muud teha. Sealt me ostame oma autod, BMW ja Audi [Saksamaa]. Maailma parimad autod, just! Ja me joome ôlut! Jah, me armastame väga ôlut, sellepärast meile meeldivad need Tšehhoslovakkia inimesed, väga hea [Tšehhi vabariik, Slovakkia]! Okei, ja see on koht, kus elab veel eestlasi, aga nad on otsustanud ennast ungarlasteks nimetada [Ungari] mingil põhjusel, ma ei tea miks. Ja siis on meil siin veel need rikkad väärakad [Austria ja Šveits]. Rikkad. Väärakad.

Ja kui läheme kaugele-kaugele itta, siis on meil seal Ühendatud Idiootide Emiraadid [Venemaa], mis katavad suure portsu maailmast. Aga meie kuningriik suutis murda koridori sellest läbi Gruusiani, mis on meie hea naaber. Me käime seal lavaši söömas ja veini joomas. Ja võibolla viinamarju.

See on siis Euroopa, meie, eestlaste, arvates.

\section{Arutelu}

Stereotüübi-küsitluse vastustest ilmneb, et kuigi ei küsitud, kui sarnased on erinevad rahvad eestlastele või kuivõrd nad eestlastest erinevad, on umbkaudu viiendik vastajaist selle spontaanselt lisanud ja vastused on üsna ühesugused. Lätlasi, eestivenelasi (vastajatepoolne eristus), sakslasi ja rootslasi peetakse eestlastele suhteliselt sarnasteks, samas soomlasi, venelasi ja ameeriklasi nähakse endast erinevatena. Hinnangud, kui lähedased või sarnased ollakse teiste etniliste rühmadega, jagunevad hea ja halva skaalale. Näiteks sakslased ja rootslased on head, ameeriklased rumalad ja halvad, soomlased ja venelased aga nii head kui ka halvad, mis tõenäoliselt on tingitud asjaolust, et tegemist on lähinaabritega, 
kellega on olemas isiklikud kogemused. Just hinnangu tagant aimuv naabri-efekt muudab vastuste ulatuse ja pildi kirevaks. Lätlased, samuti lähinaabrid, pälvivad vähe tähelepanu, neist ega nende kommetest ei teata väidetavalt eriti midagi ning stereotüübid pole sügavalt juurdunud. Näib, et nende kohta puuduvad laiemalt levinud üldised stereotüübid, stereotüüpide asemel esitati folklooripalu. ${ }^{6}$

Kõige üllatavam oli stereotüüp keelesugulaste soomlaste kohta, kes elavad eestlastest $80 \mathrm{~km}$ kaugusel üle Soome lahe ja keda peetakse meist erinevateks. Arvatavasti on sellel vähemalt kaks põhjust: üle poole sajandi kestnud vodkaturism ja ostureisid odavamale maale ning nn vanema ja jõukama venna sündroom, mis põhjustab alaväärsuskompleksi. Niisiis ei sarnane vastajate arvamusel soomlased meile, sest "soomlased on ostuturistid", "soomlased on vodkaturistid", "soomlased kannavad väga veidraid rõivaid". Soomlaste kui joodikute ja vodkaturistide imagot toetavad omakorda meedia arutlused alkoholimaksude ja aastasissetulekute üle.

Meedia mõjud ja varasem suuline traditsioon reflekteeruvad ilmselt seisukohtades, et Ameerika Ühendriigid on lihtsameelsete (lollide) ja nn Miki-hiire maa. Sotsialismiperioodi tavalisim stereotüüp võrdles ja võrdsustas USAd ja NSVLi (Nõukogude Sotsialistlike Vabariikide Liit) kui lollidemaad, mõlema riigi poliitikat ja oma kodanikesse suhtumist peeti identseks. Enamik neist stereotüüpidest ei põhine isiklikel kontaktidel, vaid on kujunenud arvamusliidrite ja meedia interaktsiooni vahendusel. Väliste tunnuste hulka, mille alusel ameeriklasi peetakse erinevateks, kuuluvad rõivastuse ja välimusega seotud hinnangud ("neil on raskusi stiiliga / nad pole stiilsed", "väga maitsetud rõivad"), kuid prevaleerivad poliitilised ("ameeriklased topivad oma nina igale poole") ja käitumuslikud: ("nad määrivad oma probleeme ülejäänud maailmale pähe"). Viimased seisukohad on kindlasti suhestatud poliitilise ja majandusliku sekkumisega erinevate maade käekäiku, aga ka Eesti telekanalitel jooksvate TV- ja eriti tõsielusarjadega, mis õpetavad inimestele lihtsaid tarkusi laste eest hoolitsemiseks, pereprobleemide lahendamiseks, majapidamise korrastamiseks, edukas koduperenaine olemiseks jne. Saadete lihtsakoeline õpetussõnum ja osaluspered võimendavad arvamusi võõrandunud ja saamatutest kodanikest.

${ }^{6}$ Lina Gergova uurimus stereotüüpidest osutab, et geograafiliselt ja kultuuriliselt kaugemate rahvaste kohta tihti stereotüübid puuduvad, kuigi võib esineda juhuslikke teadmisi ja üldistusi (Gergova 2012). 
Kummastaval kombel olid venelasi puudutavad arvamused võrreldes sotsialismiperioodiga vähe muutunud. ${ }^{7}$ Ametlikult moodustasid venelased sotsialismiperioodil Nõukogude Liidus valitseva enamusrühma ja eestlased alluva vähemusrühma. Eestlaste stereotüüpides ja huumoris väljenduvad suhted vastupidiselt, st ennast tajuti pigem enamusrühmana, mis näib toetuvat endisele, aga ka sotsialismiperioodi formaalselt kehtinud omariiklusele ning vastavalt sellel põhinevale enamusrühma tunnetusele.

Stereotüübid osutavad teatavale üleolekule, säilinud on sh stereotüübid venelastest, kes joovad pangede kaupa / klaasitäis korraga viina. Alkoholismiprobleeme kajastati meedias, kuid arvatavasti mõjutasid suhtumisi ka kohustuslikku kooliprogrammi kuulunud 19. ja 20. sajandi vene kirjandusklassikute N. Gogoli, L. Tolstoi, M. Gorki jpt kirjeldused vene elust. Seda toetas omakorda suuline jutupärimus Nõukogude sõjaväeteenistuses kogetust ja Nõukogude Liidu aegsetest padujoomingutest, kogemuslood vene immigrantidest töölistega ja viinast kui valuutast, viinaga makstud teenustest jpm. Kuigi need olid tookord ühiskonnas rahvusrühmast laiemad üldprobleemid, ei peegeldu joomine nt eestlaste autostereotüüpide hulgas.

Vastupidiselt sotsiaalteadustele, sh psühholoogiale, kus kollektiivsust peetakse sotsiaalse suhtlemise ja avatuse tunnuseks ning seostatakse seda oskusega üksteise eest vastutada või vajadusel kaitsta oma lähemat rühma, on kollektiivsusel eestlaste seas käibetõe tasandil negatiivne tähendus. Kollektiivsus tähistab (sotsialistlikku) kuulekat massi, kellel puudub vaba tahe ja kes on ülalttulevate ideoloogiliste otsuste subjekt. Seetõttu on hinnangud ameeriklastele ja venelastele kui kollektiivsetele rahvastele negatiivse tähendusega. Samasugust pejoratiivsust väljendab empiirilistel kogemustel põhinev tähelepanek, et rootslased on ülesotsialiseeritud, ettehooldatud ja neil pole reaalsusest aimugi.

Eestlaste autostereotüübid olid sotsialismiperioodil vägagi positiivsed: intelligentsed, materialistlikud, kõvad töötegijad, hea keeleoskusega, vana kirjakeelega kultuur, hea haridussüsteem, suured laulupeod, hea õlu, ilusad naised, stabiilsed, hea iseloomuga (st rahuliku loomuga), suurimaks paheks peeti eestlaste orjamentaliteeti ja liiga püüdlikku käsutäitmist.

7 Parema võrdlusainestiku saamiseks paluti juhuvaliku alusel väikesel rühmal vanuses $45-80$ aastat meenutada stereotüüpe venelaste ja ameeriklaste kohta. 
Eestlaste enesehinnang ja autostereotüübid on muutunud. Siiani loetletakse teatud hulka varasemaga sarnanevaid tunnuseid, nagu individualism (positiivne omadus vastajate meelest), hea haridus, keeleoskus, emotsioonide vaoshoidmine (positiivne omadus) ja töökus (või koguni töönarkomaania). Vastustest "Eesti mehed ei hinda oma naisi" ja "eesti naised eelistavad abielluda välismaale" aimuvad seosed migratsiooniga, mainitakse ka avalikke arutelusid samadel teemadel näiteks internetifoorumites. Mitmed autostereotüübid on hoomatavalt eneseiroonilised: kunagi väärtustatud omadused ja stereotüübid on huumori objekt ("armastavad metsas elada ega soovi teistega suhelda"). Üldiselt on autostereotüübid siiski positiivsed, sotsiolingvist Hille Pajupuu uurimuse põhjal olid kümnest eneseiseloomustuseks kasutatud omadussõnast kuus positiivsed (Pajupuu 2005, 7).

Osa stereotüüpe ja eelarvamusi, mida esitles lühike YouTube’i klipp, sarnanevad küsitlustulemustega. On aga ilmne, et animatsioonis ühe või teise maa ja rahva kohta lausutul lasub meedia mõju ja ajastu pitser. Kui sama klipp oleks loodud aastal 2010, oleks Islandi puhul kindlasti loodud seos tuhapilvega ja Kreeka võinuks olla märgitud puhkamist segavate tänavarahutustega. Gruusia pälvis tähelepanu 2008. aasta sündmustega, mis tekitasid tugeva rahvaliikumise omasuguse väikese iseseisva riigi ("just nagu meie") kaitseks, keda rõhub "kuri Venemaa". Nõukogude ajal liigitasid streotüübid grusiinid, nagu paljud teised rahvad, "nõukogude asiaatide" ehk "mustade" hulka, st suhted polnud kuigi soojad, viimase paarikümne aasta jooksul on olnud vähe kontakte. Animatsiooni postitamise ajal oli Gruusia olukord veel aeg-ajalt uudiste teema ja sentiment tugev.

Terve rida lausumisi on mõistetavad üksnes Eesti pressis avaldatu kontekstis (näiteks Iirimaa kui lihttööliste migratsiooni sihtpunkt, kus käiakse mh kalkuneid kitkumas; rikkad Eesti kriminaalid on omandanud tegelikkuseski maavaldusi Hispaania rannikul). Eestlased on ligi sajandi olnud uhked oma suusatajate üle, "kes on peaaegu sama head kui Norra ässad", meie professionaalsel jalgpallimeeskonnal on kehv tase ja Andorra meeskond laiemalt Euroopas tuntud niru meeskonna poolest, nii et animatsioonis lausutud: "Neil on maailma ainuke meeskond, kellele me iial oleme

${ }^{8}$ Mudeleid "eesti naised eelistavad välismaalasi (venelasi, neegreid)" jm seksuaalse konnotatsiooniga hinnanguid ning huumorit oli liikvel juba sotsialismiperioodil. 
ära teinud," tekitab vaatajates mõnusa elevuse. Austria ja Šveitsi kõrge elustandard paneb kadestama ("rikkad värdjad") ning nn naistevarguselgi on tõsielutaust - Türgil ja Eestil on mõlemal suur osalus sotsiaalmeedia keskkonnas Orkut, kus türgi mehed flirdivad eesti naistega, mis on viinud mitmete abielusidemeteni.

Viited Lätile ja Soomele on tihedas seoses universaalse naabrite eiramise ja nöökamistega. Keelebarjääri ja nõrkade kaubandussuhete tõttu on Läti harva Eesti meediauudistes ja ka omavaheline informaalne kommunikatsioon pole tihe. See ei takista eestlasi naljatamast teemal, et lätlastel on kuus varvast ("loogikat" selliste väljendite taga selgitavad nt YouTube'i kasutajate kommentaarid) ja nad on muulgi moel veidrad. Lätil pole tõepoolest saari, erinevalt Eestist, millel on sadu eri suuruses saari, kuid neil on (erinevalt klipis väidetust) pikk mererannik, eestlastel on nendega olnud korduvalt vaidlusi kalapüügiõiguste üle ("räimevargad"). Soomlasi on pikka aega kutsutud põtradeks, valdav on vodkaturisti imago, ehkki kahe maa vahel on kaubandussuhted, tavalised on omavahelised abielud ja Soome on üks peamisi töömigratsiooni sihtpunkte - isiklikud kogemused ja meedias edastatav on unisoonis, mis pole leevendanud stereotüüpide negatiivseid külgi.

Venemaa on pikima ühispiiriga ja konkurentsitult suurim naaberriik, kelle kohta väljendati samuti negatiivseid hoiakuid. Suhted riikide tasandil on olnud aastaid pingelised või koguni mitteandestavad. Eesti taasiseseisvus Nõukogude Liidust 1991. aastal, kuid Venemaad tajutakse siiani ohuna ja sealseid venelasi rõhujatena. Meedia edastab negatiivseid uudiseid, nooremad elanikud ei valda vene keelt ja informaalsed suhted on nõrgad. Lisaks sellele mõjutavad suhteid hiljutised sündmused Gruusias. Venemaa nimetamine Ühendatud Idiootide Emiraadiks on YouTube'i klipi üks enam positiivseid kommentaare pälvinud lausung, see tekitab naljakaid assotsiatsioone Araabia Ühendemiraatidega ning vastab inimeste sisetundele Venemaa kohta, ja nad kiidavad heaks julguse väljenduda sel kombel praeguse poliitkorrektsuse diskursuse raames. Eesti poliitikud ei riskiks iial ütelda midagi sellist, sest Eesti majandus sõltub mh Eesti kauba ekspordist Venemaale, mida mõlemad pooled teavad piisavalt hästi. Teise supervõimu USA suhtes on animatsiooni solvavad ütlused piiratud, sest skoop on Euroopal (nalja teeb pigem Ühendkuningriigi ja USA uljas segiajamine, aga see on juba seotud klipi sisuliste taotlustega). 
Teisalt viidatakse Prantsusmaale konnade ja mitmele muule riigile fašistlike suhete kaudu, mis on selgesti ajendatud mõnest välismeedia produktist (võimalik, et taas Ameerika omast), mida saab kergesti jälgida rahvustelevisiooni, satelliitkanalite või kino vahendusel. Ka hinnangut fašistid on avardatud suurema koomika saavutamiseks ("pitsafašistid").

Kui loetletud põhjusi arvestada, tuleb tõdeda, et meie küsitluses saavad frustratsiooni ja võistlusmomenti põhjustada eeskätt soomlased oma kaubareiside, maade kokkuostmise ja üleoleva suhtumisega ning venelased Venemaal, mis kujutab endast suurt ressursse ohustavat ja eestlasi marginaliseerivat potentsiaali. Ameeriklaste puhul saab põhjus olla üksnes kultuuriline sekkumine, meediasurve igapäevakultuurile, ka neile globaliseerumisprotsessi negatiivsete külgede omistamine.

\section{Miks ja kuidas stereotüüpe kasutatakse}

Sotsiolingvist Hille Pajupuu mitmete uurimuste tulemus osutab, et stereotüübid naaberrahvast on mõjutatud sotsiaalpoliitilisest situatsioonist ja igapäevastest empiirilistest kogemustest rühma esindajatega. Stereotüübid hakkavad kiiresti muutuma, kui kujutletud kultuuri asemele asub vahetu kontakt etnose liikmetega. Lühikokkuvõttena osutavad kolme küsitluse tulemused, et aastatel 1991-1992 olid soomlased eestlaste meelest peaaegu ideaalne rahvas, kümnest soomlasi iseloomustavast omadusest üheksa olid positiivsed. Aastatel 1996-1997 iseloomustati soomlasi räuskavate ja ülbete joodikutena, kümnest omadusest üheksa olid negatiivsed. 2005. aastaks oli suhete teema rahunenud ning positiivne ja negatiivne pool tasakaalus (Ehasalu 2010). Jüri Uljase 1995. aastal Tallinnas ja Helsingis läbi viidud küsitlusest ilmnes, et olulisel kohal oli isiklike kontaktide kõrval massikommunikatsioonivahendite abil loodud pilt. Jüri Uljas toob esile nn paremuse teisest rahvusest ning tema uuringu tulemuste põhjal on eestlaste arvates soomlased eestlastest paremad eelkõige kahe tunnuse osas: jutukuse ja rikkuse poolest. Soomlaste enesehinnangu kohaselt olid nad eestlastest kõiges paremad: neil on näiteks paremad teadmised, nad on vabamad jne (Uljas 1998). Kindlasti on põhjust uurida soomlaste stereotüüpe eestlaste kohta uuesti praegu, massilise töömigratsiooni ja halvustava meediakuvandi taustal. H. Pajupuu artiklist ja M. Kõiva 
küsitluse vastustest ilmneb, et eestlased on oma autostereotüübid suures ulatuses säilitanud (Pajupuu 2005, 12). M. Kõiva küsitlused osutavad, et vanad negatiivsed hinnangud on kaotanud oma aluse (orjameelsus, orirahvas), samas on esile kerkinud uued nüansid. 1990. aastal ja selle järel tehtud küsitluste tulemused osutavad selgesti, et stereotüübid on õige tundlikud poliitilis-majanduslikele ja kultuurilistele survetele ning mitmes suhtes määrab tulemuse ka vana tõdemus, et subordineeritud rühma enesehinnang erineb dominantse rühma arvamustest tema kohta (vrd Uljas 1998). Et teostatud uuringud on metoodikalt ja käsitletud aspektidelt erinevad, on keerukas rakendada detailset võrdlust, peamised järeldused on et: a) stereotüübid kohandatakse uute sotsiaalkultuuriliste oludega;

b) etnilise rühma erinevad segmendid ja isiksused reageerivad muutustele erineva kiirusega, mistõttu korraga käibib uuemaid ja vanemaid stereotüüpe;

c) üksikute rahvusrühmade suhtes võivad stereotüübid konkreetsete olude tõttu aktiveeruda ja teravneda, millele järgneb vaibumisperiood;

d) teatud stereotüübid võivad olla ajaliselt pikalt aktuaalsed (venelased ja soomlased ning alkoholilembus);

e) YouTube'i animatsioon toob esile meedia, sotsiaalmajanduslike ja kultuurikontaktide mõju vanade stereotüüpide kasutamisele ja uute akumuleerimisele;

f) ühiskonnas on käibetõdede ja muude kategooriate omaksvõtt ja sellega seotud käitumuslik väljund just nii vaba, nagu seda kirjeldab Undo Uus.

Stereotüpiseerimise taga on hulgaliselt sotsiaalkultuurilisi ja poliitilisi põhjusi, kuid nad, eriti aga nende verbaalne väljendamine, on tugevasti seotud ka isiksuse ja identiteediga. Väidetavalt on stereotüüpide kasutamise tüüppõhjusteks lisaks nende abile otsuste langetamisel frustratsioon, agressioon ja frustratsiooni vallandumine sõnalise agressioonina. Muzafer Sherif ja paljud teised uurijad on juhtinud tähelepanu autoritaarsetele isikutele, kes projitseerivad negatiivsed tunded teisele sotsiaalsele rühmale: "Meie oleme head ja targad inimesed, kes väärivad oma positsiooni. NEMAD on [---] kuna neil on ebameeldivad iseloomujooned, nad käituvad halvasti, neil on rumalad või vanamoodsad kombed" (Sherif 1966, 37 jj). Arvamusliidrite ja võimulolijate sedalaadi sõnumid muudavad väga kiiresti osa ühiskonnaliikmete üldhoiakuid ja loovad uusi üldistusi. See ilmnes selgesti Euroopa Liidu majanduskriisi tingimustes, kus 
nt kreeklaste kohta loodi rida negatiivseid stereotüüpe. Rühmadevaheline võitlus ressursside (maa, vesi ja teised loodusvarad) pärast viib vaenuavalduste ja eelarvamusteni.

Kognitivistid toetasid varem üsna üksmeelselt arvamust, et stereotüüpide puhul lasub süü ekslikul mõtlemisel, kuigi me ei pruugi olla teadlikud, et teeme vigu teistest mõtlemisel (Allport 1954). Kultuuriline kompetents väidetavalt muudab stereotüüpe. Näiteks George Kelly väitel ei taju me sündmusi otse, vaid pigem on meie sündmustetaju ehitatud üles šabloonidele või kategooriate võrgustikule, mida me konstrueerime, organiseerimaks fenomeni pertseptsiooni. Etnotsentriline kogemus on üksnes võimalus sündmuste tajumiseks, kogemus sõltub isiksuse poolt konstrueeritud sündmusest (Kelly 1963, 34 jj). Milton Bennett täpsustab, et kultuuridevahelise kompetentsi tuum on võime konstrueerida alternatiivseid kultuurilisi kogemusi. Monokultuurilise sotsialiseerumisega indiviididel on üldjuhul juurdepääs üksnes oma kultuuri maailmavaatele, mistõttu nad ei ole nad võimelised kogema erinevusi oma tajude ja kultuuriliselt erinevate inimeste tajude vahel. Kultuuridevaheline tundlikkus annab võimaluse luua alternatiivseid kogemusi, mis vastavad enam või vähem teisest kultuurist pärit inimeste kogemusele. Samuti on see alus võimele esindada kultuuridevahelist maailmavaadet (Bennett 2004, 62).

Stereotüüpidega seotud teemad on tihedalt põimunud igapäevaelu erinevate aspektidega. Kui üldstereotüübid on osa meie kultuurilisest kompetentsist, siis eelduspäraselt on meile sarnased rahvad meile sarnaste stereotüüpidega. Niisiis moodustavad Euroopa rahvaid puudutavad stereotüübid aluse kultuurilistele sarnasustele ja erinevustele, st ühise kultuurilise konteksti, nagu seda kirjeldas Milton Bennett.

Artiklis vaadeldud eestlaste stereotüübid teiste rahvuste kohta on tänapäevane mikstuur jagatud isiklikest kogemustest, meediaallikatest inkorporeeritud vahendatud kogemustest ja deklaratiivsest retoorikast; stereotüüpe ja eelarvamusi hoiavad elus erinevad mehhanismid. Osa neist jagab laiem Euroopa auditoorium, nagu kinnitavad kommentaarid YouTube'i animatsioonile. "Stereotüübid on uskumuste kompleksne võrgustik, mida hoiavad vahel koos kultuuriline liim või eelarvamused, aga sageli teooriad, mis reflekteerivad mõnda kogemuste kombinatsiooni ja kultuuri" (Schneider 2004, 566). 


\section{Kirjandus}

Allport, Gordon W. 1954. The Nature of Prejudice. Cambridge, MA: AddisonWesley.

Bennett, Milton J. 2004. Becoming Interculturally Competent. - J. Wurzel (toim). Toward Multiculturalism: A Reader in Multicultural Education. 2. tr. Newton (MA): Intercultural Resource Corporation, 62-77 (http://www.idrinstitute.org/allegati/idri_t_pubblicazioni/1/ file_documento.pdf - 19.05.2013).

Gergova, Maksimova Lina 2012. Етнически стереотипи във всекидневната култура. Sofia: Paradigma.

Gilbert, Gustav Mark 1951. Stereotype Persistence and Change among College Students. - Journal of Abnormal and Social Psychology, $46,245-254$.

Järv, Risto 1996. An Outline of Everyday Credos: from the Aspect of Gender and Profession. - Kõiva, Mare (toim). Contemporary Folklore: Changing World View and Tradition. Contemporary Folklore 1, 213-233.

Karlins, Marvin; Coffman, Thomas L.; Walters, Gary 1969. On the Fading of Social Stereotypes: Studies in Three Generations of College Students. - Journal of Personality and Social Psychology 13 (1), 1-16.

Katz, Daniel; Braly, Kenneth W. 1933. Racial stereotypes of one-hundred college students. - Journal of Abnormal and Social Psychology 28, 280-290.

Kelly, George 1963. A Theory of Personality. New York: Norton.

Korb, Anu 2011. The Adaptation of Russian-Born Estonians and the Sharing of Remigration Stories. - Garda-Rozenberga, Ieva; Zirnite, Mara (toim). Oral History: Migration and Local Identities. Riga: National Oral History Archive, Institute of Philosophy and Sociology, University of Latvia, 90-104.

Korb, Anu 2012. Siberi eestlaste kohanemisest ja sulandumisest pärimusainese põhjal. - Mäetagused 50, 47-70 (http://www.folklore. ee/tagused/nr50/korb.pdf - 19.05.2013).

Krikmann, Arvo 2008. "ATU jokes": old and abandoned. A paper presented to the ISHS 20th Annual Conference hosted by the University of Alcali (Alcali de Henares, Madrid, Spain) July 7-11, 2008 (http:// haldjas.folklore.ee/ kriku/HUUMOR/KRIKMANN_ATU_ready. pdf - 19.05.2013).

Krikmann, Arvo 2009. Jokes in Soviet Estonia. - Folklore: Electronic Journal of Folklore 43, 44-66 (http://www.folklore.ee/folklore/vol43/ krikmann.pdf - 19.05.2013).

Krikmann. Arvo 2009. On The Similarity and Distinguishability of Humor and Figurative Speech. - Trames 13 (63/58), 1, 14-40.

Kõiva, Mare 2012. Adapteerumisjutud Austraalia eestlaste näitel. Mäetagused 50, 113-140 (http://www.folklore.ee/tagused/nr50/koiva. pdf - 19.05.2013). 
Kõiva, Mare; Vesik, Liisa 2011. "Yurop" according to Estonians: some ethnic stereotypes. - Witalisz, Alicja (toim). Prace naukowo-dydaktyczne Panstwowej Wyzszej Szkoly Zawodowej w Krosnie. Papers on Language, Culture and Literature. Zeszyt 55(3). Krosno: Krosno University, 147-158.

Laineste, Liisi 2004. Characters in Estonian Ethnic Humour (1890-2004). - Folklore: Electronic Journal of Folklore 27, 197-202 (http://www. folklore.ee/folklore/vol29/humour.pdf - 19.05.2013).

Laineste, Liisi 2008. Politics of Joking: Ethnic Jokes and their Targets in Estonia (1890s-2007). - Folklore: Electronic Journal of Folklore 40, 117-145 (http://www.folklore.ee/folklore/vol40/laineste.pdf 19.05.2013).

Lippmann, Walter 2003 [1922]. Public opinion. New York: Harcourt, Brace. Madon, Stephanie; Guyll, Max; Aboufadel, Kathy; Montiel, Eulices; Smith, Allison, Palumbo, Polly; Jussim, Lee 2001. Ethnic and National Stereotypes: The Princeton Trilogy Revisited and Revised. - Personality and Social Psychology Bulletin 27 (8), 996-1010.

Pajupuu, Hille 2005. Estonian National Stereotypes in Transition. - Petkova, Diana; Lehtonen, Jaakko (toim). Cultural Identity in an Intercultural Context. Publications of the Department of Communication, No 27, Jyväskylä: University of Jyväskylä, 124-142.

Psychology Dictionary 2012. World's Most Comprehensive Online Psychology Dictionary (http://psychologydictionary.org/ - 19.05.2013).

Põldmäe, Rudolf 1941. Eesti rahvanaljandid I: Inimese eluperioodid. Tartu: Teaduslik Kirjandus (Online 2001: http://www.folklore.ee/rl/pubte/ ee/nali/ - 19.05.2013).

Schneider, David J. 2004. The Psychology of Stereotyping. New York: Guilford Press.

Sherif, Muzafer 1966. In Common Predicament: Social Psychology of Intergroup Conflict and Cooperation. Boston: Houghton Mifflin Company.

Uljas, Jüri 1998. Eestlased ja soomlased teineteise peeglis. - Eesti Ekspress. Areen 7 (427), B6 (http://paber.ekspress.ee/arhiiv/Vanad/1998/07/ areen/uurimus.html - 19.05.2013).

Uus, Undo 2000. Science and Folk Sentiments. - Folklore: Electronic Journal of Folklore 15, 7-23 (http://www.folklore.ee/folklore/vol15/science. htm - 19.05.2013).

\section{Summary}

\section{Europe According to Estonians I. About Ethnic Stereotypes}

Keywords: auto-stereotype, common truth, ethnic stereotypes, prejudice, stereotype, YouTube 
An extensive literature exists related to the stereotypes in the social sciences, at the same time the phenomenon paid a little attention in humanities. In Estonian folkloristic, the term käibetõde 'common truth' is used to mark both prejudices and stereotypes. Certainly part of the set of the beliefs, figurative speech samples, humour, also Diaspora-narratives is based on stereotypes.

We are going to have a look at stereotypes Estonians have of six other nations /ethnic groups. One source we are going to review is survey questionnaire results (conducted in 2001 and 2005) about stereotypes, the second is the Estonian-produced animation posted to YouTube in 2009. The animation "“Yurop" According to Estonians" (2009) demonstrates how stereotypes interact with common beliefs and stereotypes in society, and with the media.

Latvians, Estonian Russians, Germans and Swedes were seen as quite similar to Estonians, through positive stereotypes, while Finns, Russians and Americans were seen as not similar to Estonians. References to Latvia and Finland are closely connected to the universal disregard all nations have towards their neighbours. However, due to the language barrier and lack of strong trade connections, Latvia is seldom on Estonian news and there is little informal communication. Finns, however, are universally nicknamed 'moose', and the vodka tourist image prevails, even though there are trade connections as well as intermarriages and work migration to Finland - personal experience and media coverage work in unison in that direction. Strangely enough, opinions about Russians have changed little since the time of the Soviet Union. Russia is seen as a superpower country. The relations have been tense, or unforgiving, for years. Estonia became independent from the Soviet Union in 1991 and Russia is still seen as a threat, the stereotypical evaluations extrapolate that Americans and Russians are mass /collective people, and the feature is seen as something negative.

Estonians' auto-stereotype during the Soviet time and shortly after the re-independence was very positive. In 2000ies still list characteristics like good education, control of emotions, hard-working (or even workaholics). However, there are also generalizations that Estonian men not value their women, Estonian women prefer to marry abroad. Some stereotypes are perceptibly self-ironic. Results of sociolinguist Pajupuu indicate that 6 out of 10 auto-stereotypes are positive (Pajupuu 2005, 7).

The issues connected with stereotypes are complicated and tightly interwoven with various aspects of everyday life. Common stereotypes are part of our cultural competence. The stereotypes Estonians have of other nations are a mixture of shared personal experience and experiences incorporated from media sources, fueled by different mechanisms that keep stereotypes and prejudices alive. Some of these are characteristic and shared by the larger European audience, as confirmed by comments to the YouTube animation. 


\section{MAAILM ja \\ MULTITASKING}

\section{Koostanud ja toimetanud MARE KÕIVA}

http://www.folklore.ee/rl/pubte/ee/cf/multi

ISBN 978-9949-544-01-1

Tartu 2014

Trükis ilmunud:

MAAILM ja MULTITASKING. Tänapäeva folkloorist 10.

Tartu 2014

Sarja peatoimetaja: Eda Kalmre

Kogumiku koostaja ja toimetaja: Mare Kõiva

Keeletoimetaja: Asta Niinemets

Kaanekujundus: Lilli-Krõõt Repnau

Küljendus: Diana Kahre

HTML: Diana Kahre

Trükist toetasid: teadusteema SF 0030181s08, ETF grant nr 8137 ja IUT22-5 ning Eesti Kultuurkapital.

E-raamatu valmimist toetas: EKKM14-344 Eesti keele, kultuuri ja folkloori kasutusalade laiendamine ja tutvustamine elektroonilistel infokandjatel.
(C) Mare Kõiva
(C) autorid
(C) EKM Teaduskirjastus 2014 